\title{
Moral Equivalence
}

\section{The Story of Genocide Denial in Rwanda}

\author{
Linda Melvern \\ linda@melvern.co.uk
}

\begin{abstract}
Since the very beginning of the Rwandan Genocide of the Tutsis in 1994, members of Hutu Power, the Akazu, and other interested allies of the former government of Rwanda have been conducting a campaign of genocide denial, one in which they blame the Tutsi dominated Rwandan Patriotic Army for carrying out murder of civilians during the civil war in 1994. In this article Linda Melvern examines the role that Hutu Power played in creating the myth of a counter-genocide and the unwitting legitimacy that was given to it by several UN agencies and their associated employees and consultants. Melvern notes that despite overwhelming evidence that demonstrates that there was no 'counter genocide', the lies and misinformation planted in the early post-genocide days persist, with some authors making new unsubstantiated claims about a slaughter of those Hutu who did not flee the country in July 1994.
\end{abstract}

\section{Keywords}

Gersony report - UNHCR - genocide - refugees - UNAMIR - genocide denial

From the moment when the leadership of Hutu Power seized control of the government of Rwanda on the evening of 6 April 1994, it had determined to distort the reality of events surrounding the genocide to the outside world. The United Nations was central to these plans. In a sad irony the General Assembly had elected Rwanda to one of the 10 non-permanent seats in the Security Council, and so when the genocide of the Tutsi was getting underway in April 1994, the genocidaires had an ideal forum to promote the denial of their crime and spread fake news and disinformation in the meetings, hallways and lounges of the United Nations' New York headquarters. 
The foundation stone upon which the campaign of genocide denial had depended was that, far from being organised, the widespread killing throughout the country had resulted from a "spontaneous" uprising. In the wake of the resumed civil war with the Rwanda Patriot Front (RPF), the population attacked neighbours in fear and in anger. According to this narrative, there was no planning; the massacres were a failure of the human condition and followed centuries-long hatreds and in this "inter-ethnic" killing, both sides were to blame.

The notion of moral equivalence in the circumstances of the 1994 genocide of the Tutsi persists to this day. The idea of two genocides, the first nearly wiping out the Tutsi minority, and the second secretly committed by the Tutsidominated RPF against Hutu, would have been a sensational news story, if true. In July after the RPF achieved military victory there was a proliferation of rumours about human rights abuses committed by these troops. A US journalist, Mark Fritz, spent nearly a month looking for evidence but found nothing. A British journalist reporting from Rwanda for the $\mathrm{BвC}$, Mark Doyle, wrote a dispatch to London explaining no convincing evidence existed of the RPF massacring civilians. Doyle warned the в вС news desk not to broadcast claims about RPF abuses until some convincing evidence emerged. 'I used to take regular calls from ввС editors in London asking me to make sure I put the other side', Doyle wrote later. Doyle told them this was not a balanced picture, and there was no moral equivalence. Another experienced UK journalist, Mark Huband of the Observer noted only 'second-hand reports' about RPF killing coming from the UN High Commission for Refugees (UNHCR), and the vast newly created refugee camps on Rwanda's borders.

The over-flowing refugee camps in neighbouring countries in the aftermath of the genocide of the Tutsi were the result of one of the more calculated strategies devised by the Hutu Power leadership. In inciting the population to flee, a stream of fake news in bulletins on radio RTLM called on the 'Hutu nation' to immediately leave the country. In response whole communities took to the roads. The resulting exodus, during which an estimated two million people fled from Rwanda, broke world records and was unprecedented in speed and size. In Tanzania, an estimated 500,ooo people settled at a camp called Benaco. Two hundred thousand refugees fled to Burundi. An estimated 1 million people passed into Zaire at Goma, and 200,00o more into Bukavu. ${ }^{1}$

1 Larry Minear and Philippe Guillot, Soldiers to the Rescue: Humanitarian Lessons from Rwan$d a$, Development Centre of the Organization for Economic Cooperation and Development, Paris, 1996, 63. 
These people were not, as some journalists and aid agencies later supposed, fleeing the genocide; they included the Interahamwe militia and the authorities who planned and perpetrated the crime of genocide. The camps were beyond the reach of international justice and in these murderous and terrible places the Hutu Power authorities kept control. The same administrative structures that existed in Rwanda were swiftly re-created - the préfectures, communes, secteurs and cellules. ${ }^{2}$ The bourgmestres, were the same men who had issued the orders to kill Tutsi. Soon a web of Hutu Power committees, neighbourhood security units and associations embraced almost all segments of refugee society. ${ }^{3}$ The threat from the militia prevented international agencies from registering the refugee population, and as a result of the exodus, the region risked destabilisation. Rwanda, in the words of one US diplomat, was surrounded by a "constrictive belt of insecurity". The Hutu Power forces launched attacks into Rwanda from these camps, one of which (Mugunga) contained the defeated Rwandan government army of 33,00o troops along with weapons that had been supplied from French military stocks.

In late July and early August, a trickle of refugees returned home but the movement soon slowed. While the return and resettlement of refugees was considered essential to Rwanda's future long-term stability, aid agency staff in the camps watched a determined campaign to prevent people from returning. The refugees were told that any Hutu who went back to Rwanda would be massacred immediately by the RPA. ${ }^{4}$ There were anonymous pamphlets distributed claiming that no one who had returned tp Rwanda from the camps had survived. ${ }^{5}$

One practical attempt to counteract this Hutu Power propaganda in the camps came from a UN headquarters staff member, a Canadian officer, Phillip Drew who served in the UN Assistance Mission for Rwanda (UNAMIR II). Drew designed leaflets to be dropped into the camps from UN helicopters visually portraying Rwanda as a lush and fertile place of safety showing security, fresh water and food. The plan backfired when at the last minute the UN guarantee of safe passage to returning refugees was put on hold when the UN discovered that possession of one of these leaflets by refugees in the camps was tantamount to an automatic death sentence.

In September the repatriation policy that UNAMIR II tried to foster was thrown into disarray. A panicked phone call to UN secretary-general, Boutros

2 The International Response to Conflict and Genocide, Volume 3, 96.

3 Fiona Terry, Condemned to Repeat? The Paradox of Humanitarian Action, Ithaca: Cornell University Press, 2002.

4 Laurence Binet, 'Genocide of the Rwandan Tutsis', MSF Speaking Out, September 2003.

5 Rwanda and Burundi, The Return Home: Rumours and Realities, Amnesty International, January 1996, Cited in Fiona Terry. 
Boutros-Ghali in New York from the UN High Commissioner for Refugees (UNHCR), Sadako Ogata, in Geneva had some disturbing news. Ogata told Boutros-Ghali that information received by her office showed the RPF troops had slaughtered 30,00o Hutu civilians in systematic and preordained massacres as they took control of the country. The information had come from an experienced consultant Robert Gersony, a US national contracted for sixty days by the UNHCR to organise a voluntary repatriation programme for refugees. Only later did it transpire that Gersony had secretly briefed US officials on his findings, the information reaching Brian Atwood, appointed by President Bill Clinton's special envoy to Rwanda. Information in declassified US state department documents reveals a briefing on September 20 when Gersony provided US officials with graphic descriptions of how RPF troops hunted Hutu from house to house and their weapons hoes, axes, machetes and fire. The burial of bodies was a problem. As the team travelled towards the southeast, they found the stench of recently dead bodies was overpowering.

Gersony told US officials that the voluntary repatriation of the refugees currently promoted by the UNHCR could under no circumstances be justified. A return home for Hutu refugees was too dangerous. According to US cables Gersony dismissed reports of Hutu Power intimidation in the camps. From his recent interviews in the camps there was little evidence of forcing refugees to stay put. Gersony had apparently over a five-week period met privately with 200 refugees on a random basis, and his team of three experts had visited 41 of Rwanda's 45 communes. ${ }^{6}$

The information from Gersony ran counter to all the intelligence received in the US State Department that confirmed that the RPF had killed Hutu in battle, and while the RPF had admitted to targeting extremist Hutu whom it believed to be responsible for the massacre of Tutsi, generally the RPF protected Hutu within the territory it controlled. A partly declassified memorandum from Toby T. Gati to George Moose, the assistant secretary of state for African Affairs, on 16 May 1994, informed him of the killing of Tutsi behind government lines with systematic executions by government-supported militias. Unlike these government forces, the RPF did not appear to have committed what was called in the cable "Geneva Convention-defined genocidal atrocities".

The Gersony story was meet with consternation in the ranks of UNAMIR. That revenge killing by RPF soldiers took place was not in dispute; what was shocking was the claim of massacres of Hutu civilians in a systematic and targeted way. There were no reports of such killings in any UNAMIR reports.

6 The Gersony team of three people with anonymous Rwandan interpreters claimed to have visited nine UNHCR refugee camps and ninety-one locations in Rwanda with more than 200 individuals interviewed. There were 145 communes in Rwanda. 
Additionally the RPF policy of conducting courts martial and punishment of soldiers for revenge killings suggested there was no such RPF campaign. Irrespective, the unverified information from the UNHCR consultant spread like wildfire. $^{7}$

'It was a major crisis on our doorstep', recalled the recently appointed UN Special Representative for Rwanda, Ambassador Shaharyar M. Khan, a former foreign minister of Pakistan, who arrived in Kigali on 4 July 1994. The Gersony figures challenged the credibility of the UN and cast doubt on the competence of the new Force Commander of UNAMIR II, Canadian general Guy Tousignant, who arrived on 16 August $1994 .{ }^{8}$ He was keen to explain how the UN was fostering a climate of trust and confidence to prepare for refugee return.

In UN headquarters, secretary-general Boutros-Ghali determined to brief the security council on this dramatic turn of events and the under-secretarygeneral Kofi Annan, then head of the Department of Peacekeeping Operations (DPKO) was dispatched immediately to Rwanda. Annan met with Gersony in Kigali and was given an oral briefing from notes Gersony kept in his pocket. Gersony described to Annan how the RPF conducted their massacres used 'subtlety and finesse, covering their tracks with greater dexterity than the militia' when they carried out their killings. Gersony believed that between 25,000 and 45,000 people had been killed by the RPF including 5,000 people in August. Listening to these accounts with disbelief was the UN special representative for Rwanda Ambassador Khan, who was aware that UN Military Observers and aid agencies staff were present in the areas Gersony talked about. Khan wondered how it was be possible to massacre 30,000 people without attracting attention. In any case, the RPF did not travel with hoes and machetes. When briefing members of the new Rwandan government the following day, Gersony told them there had been 'a mass genocide by the RPA.'

At a later meeting at UNAM IR headquarters in Kigali, the deputy Force Commander, Brigadier-General Henry Anyidoho, and Colonel Isoa Tikoca, head of the UN Military Observers (MILOBS) decided to verify the information Gersony provided. They dispatched experience military observers to those places Gersony mentioned in his briefings. Afterwards these officers were convinced that Gersony and his colleagues were the subject of planted and dramatized evidence. Charles Petrie, deputy director of the UN Rwanda Emergency Office (UNREO), who also heard rumours about RPF massacres, carried out a careful investigation with the aid agencies in the region, and he rejected the idea of

7 African Rights, 'Death, Despair, Defiance', August 1995, 1084-5.

8 UNAMIR became UNAMIR II on 17 May 1994 under Security Council resolution 918.

9 UN Document, Outgoing Code-cable, The Gersoni Report, Rwanda, To Annan, Goulding, From Shaharyar Khan, UNAMIR Kigali, 14 October 1994. 
preordained massacres. UNAMIR information officers investigated three out of seven cases of alleged RPF abuses, and all three were inaccurate, if not outright fabrications. ${ }^{10}$

Annan and Khan personally visited some of the sites mentioned by Gersony and asked peacekeepers, doctors and engineers working at the grassroots level in the communes about the treatment of returning Hutu to the region. They were told Hutu who left in panic were returning, but there were pockets of territory still under the control of Hutu Power. Khan recalled that the descriptions given to Gersony were generally accurate, but the identity of the perpetrators and victims transposed. Khan visited a team of US and Canadian doctors in a region Gersony identified as 'the massacre belt', and none of the medical staff confirmed the claims. The US also wanted to put the Gersony claims to the test. In Kigali, the US military attaché Tom Odom believed that 10-15,000 secret killings a month inside a UN-monitored area as small as Rwanda was a startling figure.

At the direction of the Force Commander, Canadian intelligence officer Phillip Drew was tasked with the establishment of a team to investigate. The team assembled was multi-national; a group of intelligence officers of different nationalities recruited to work with criminal investigators from several UN contingents and non-troop contributing nations. With the protection of members of the Canadian contingent the team left Kigali headed first to the village of Zaza. The team included a forensic entomologist who was able to determine the approximate date of death of the human remains. The first massacre site was in the south-west, near Kibungo, where Gersony said many Hutu had been slaughtered in the school a few weeks earlier. Drew recalled how arriving at the school they found partially decomposed bodies everywhere, including in cisterns, wells and latrines. Many of the human remains in the classrooms and outdoor compounds had skeletonized, and identity cards found on some of the bodies showed victims were Tutsi. Drew recalled finding a diary. "There was an entry describing how Hutu Power beheaded its victims. The diary stopped on April 14, the most likely date of this massacre", he remembered.

A forensic examination of the bodies by the entomologist established the killing had taken place from mid to late April, when Hutu Power was in control of the area as the genocide of the Tutsi progressed countrywide. In the days to follow the intelligence team visited each site Gersony mentioned and failed to corroborate any of his claims. Many places had seen large numbers of killings, but of Tutsi. Drew never forgot these terrible days as the team visited successive massacre sites. After they finished their work they concluded that Gersony

$10 \quad$ US State Department, Rwanda/Burundi Situation Report, 23 September 1994, Declassified in full. 
and his colleagues had been duped by people in the refugee camps in Zaire. The génocidaires were trying to pin the blame on the RPF while hiding from justice in the camps, knowing exactly where in Rwanda dead bodies were located. Some speculated that Gersony never set foot in Rwanda and that he relied entirely on information gleaned in the camps. The individual reports written by the intelligence officers in this unique investigative mission remain hidden in government archives. ${ }^{11}$ Odom never did believe the RPF was systematically killing Hutu in Rwanda. ${ }^{12}$ 'We found old massacre sites but nothing new', he wrote later. Odom believed there were killings, but they were probably isolated acts of revenge. Meanwhile, Odom reported, Hutu Power was rearming in the camps. ${ }^{13}$

Declassified documents from the US State Department reveal that the French were also dismissive of the Gersony claims. In Kigali a French diplomat, Jacques Courbin, told a US counterpart that the UNHCR had bungled the Gersony report. There had been serious lapses and the collection of inaccurate data. 'In some cases, they had charged the RPF with site-specific atrocities on dates when the sites were not yet in RPF hands', Courbin reported. 'The nonreport was flawed, and he doubted that the RPF had engaged in pre-planned systematic killing as it advanced', a US diplomat reported to Washington. ${ }^{14}$

As a result of the numerous investigations conducted by various teams and officials, the senior UN officials on the ground, Major General Tousignant and the UN Special Representative, Shaharyar Khan, along with the US ambassador David Rawson and others, eventually dismissed the Gersony allegations. Gersony was invited to take part in a joint investigation team established with four Rwandan ministers and four UN representatives, but declined. No Gersony report emerged and his claims ran counter to a tide of overwhelmingly contrary evidence. This did not matter to the media. Three days after Robert Gersony met Kofi Annan in Kigali, when Annan assured him there would be an investigation into his claims, the Gersony figures appeared in the New York Times, reporting 'an unmistakable pattern of killings and persecution' by soldiers of the RPF and 'aimed at Hutu populations'. Gersony achieved his wish and in a reversal of UN policy the peacekeepers of UNAMIR II stopped further efforts to encourage refugee return.

11 Interviews with Dr. Phillip Drew, Associate Professor, Australian National University, College of law, 2019 .

12 US State Department, Country Director's evaluation of post reporting for Rwanda, From Ste to Kigali, State 307914, 16 November 1994.

13 Thomas P Odom, Journey into Darkness: Genocide in Rwanda, College Station, TX: Texas A\&M University Press, 2005.

14 US State Department, Kigali 02142, '11/10 Tour d'Horizon with French chargé', From Kigali to Secretary of State, Washington, 10 November 1994. 
On 11 October 1994 Gersony briefed the members of the Commission of Experts, established by the UN Security Council to investigate the 1994 genocide of the Tutsi. He spoke of systematic and sustained killing and persecution of the civilian Hutu populations by the RPF between April and July 1994. He claimed large-scale indiscriminate killings of men, women and children, including the sick and elderly, had been consistently reported. The only written account of the Gersony claims is a precis of what he told this meeting.

In 1999, the Gersony figures were published in a Human Rights Watch report book by Alison Des Forges after a personal briefing. ${ }^{5}$ She described the figures as the 'first convincing evidence' of widespread, systematic killings by the RPF and claimed that the UN suppressed 'the Gersony report' by claiming it did not exist. ${ }^{16}$ Des Forges described how Gersony had spoken to a wider number and variety of witnesses than any other foreigners working in Rwanda during this period. She somehow forgot the UNMILOBS and the peacekeepers of UNAMIR, present in Rwanda in some cases since October 1993 and some of whom had thoroughly investigated the Gersony claims and dismissed them as just not credible.

In the years that followed, there were dramatic increases in the death toll of these supposed RPF killings. In February 1996, Libération published an investigation by journalist Stephen Smith. The investigation examined claims of Hutu people allegedly killed by the post-genocide regime and estimated that there were more than 100,000 victims during the RPF's first year in power. Libération published an eyewitness account of a Rwandan nurse who described sites, one near Kigali, where prisoners were put to death (their skulls were crushed), and another in a game reserve, the Akagera National Park, where scores of Hutus were cremated.

It did not end there. In a sensationalist book published in 2018 called In Praise of Blood a Canadian journalist, Judi Rever, claimed a second genocide of the Hutu took place and that the methods used resembled those of the Nazis. According to her account, the RPF had established death camps that included cremation pits. Rever claimed an estimated death toll in hundreds of thousands killed, burned or dissolved in acid, their ashes dispersed with bulldozers. Rever further alleged that the Hutu genocide was carried out in total secrecy; the mass murder leaving barely a trace, and that the western allies lent a hand in the cover-up. She also made the noxious claim that during the genocide RPF commandos infiltrated Hutu militia and "assisted directly in killing Tutsi at roadblocks".

\footnotetext{
15 Interview, Oxford, 2013.

16 Human Rights Watch/Federation Internationale des Ligues des Droits de l'Homme, Leave None to Tell the Story: Genocide in Rwanda, 1999.
} 
The UNHCR held a small internal enquiry about the events of 1994 which recognised the difficulties with a refugee leadership implicated in genocide and a wide-spread intimidation and abuse in the camps. It acknowledged that in the exodus of people from Rwanda into eastern Zaire, the political, social and security structure of Hutu Power had survived intact, thanks to the support of the international community.

Despite the UNHCR's long involvement in the countries of origin, there had existed a lack of understanding of the social, cultural and political background of the refugees. A stronger protection presence in the field, combined with a better understanding of the refugees' background, would have yielded beneficial effects, notwithstanding the extreme complexity of the problems involved. The UNHCR should have been able to rapidly develop a coherent policy to deal with the various disruptive forces active in the camps, many of whom may have been subject to the exclusion clause due to their involvement in the genocide. In future, a roster of anthropologists and other regional experts needed to be developed with specialist knowledge to provide briefings on the cultural and political backgrounds of refugees.

The pernicious influence of Hutu Power lives on in rumour, stereotype, lies and racist propaganda. The movement's campaign of genocide denial has confused many, recruited some and shielded others. Its intent is to deceive, and its purpose the destruction of truth and memory. ${ }^{17}$

\section{Biography}

Linda Melvern is a British investigative journalist. For several years she worked for The Sunday Times (UK), including on the investigative Insight Team. Since leaving the newspaper she has written six books of non-fiction and is widely published in the British press and academic journals. For the past twenty years she has concentrated on the circumstances of the 1994 genocide in Rwanda. A consultant to the Military One prosecution team at the International Criminal Tribunal for Rwanda, part of her archive of documents was used to show the planning and progress of the 1994 genocide. She is the author of the best-selling books, A People Betrayed:The Role of the West in Rwanda's Genocide, and Conspiracy to Murder. The Rwandan Genocide. Her latest book, Intent to Deceive, which examines the phenomenon of genocide denial in Rwanda, will be published by Verso in 2020 .

17 Lessons Learned from the Rwanda and Burundi Emergencies EVAL/04/96/Rev.1 By Inspection and Evaluation Service 1 December 1996. 